\title{
CROATIAN HISTORICAL MYTH, SOUTH-SLAVIC BROTHERHOOD AND THE DEATH OF THE OPERA
}

\author{
NATKA BADURINA \\ Università degli Studi di Udine
}

Izvleček: Na podlagi analize tistega, kar se je ohranilo od opere Petar Svačić, ki jo je leta 1902 $v$ Trstu uglasbil Josip Mandić na besedilo Karla Lukeža, članek obravnava idejo narodnosti, ki je krožila med mladimi Hrvati, ohranjanje patosa sublimnosti v okviru desublimacije in vpliv političnega pragmatizma na nastanek nacionalne opere in njeno recepcijo.

Ključne besede: Josip Mandić, Karlo Lukež, Petar Svačić, hrvaška opera, desublimacija.

\begin{abstract}
Starting from the analysis of what remains of the opera Petar Svačić, composed in 1902 in Trieste by Josip Mandic to a libretto by Karlo Lukež, the paper discusses the ideas of nationhood then current among young Croats, the survival of sublime pathos in the context of desublimation and the impact of political pragmatism both on the creation of the national opera and on its reception.
\end{abstract}

Keywords: Josip Mandić, Karlo Lukež, Petar Svačić, Croatian opera, desublimation.

In Trieste in 1902 two young artists - the composer Josip Mandić ${ }^{1}$ and the librettist Karlo Lukež ${ }^{2}$ - created their first opera, Petar Svačić. The work was an attempt to stage the story of the last Croatian king, Petar Svačić, who reputedly died in battle against the Hungarians in 1102, so 1902 was believed to be the 800th anniversary of his death. Svačić's defeat meant the end of the Croatian kingdom and brought Croatia into a political union with Hungary that would last until 1918 . During the $19^{\text {th }}$ century nation-building process the defeat offered the basis for the creation of a powerful narrative about how the golden age

1 Mandić was born in 1883 in Trieste. His musical training took place in Zagreb, Trieste, Vienna and Prague. After early works combining the South-Slavic musical heritage and the influence of R. Wagner, he followed the currents of European music of his time. Critics noticed echos of G. Mahler, R. Strauss and L. Janáček in his work. See Muzička enciklopedija, s.v. "Mandić, Josip"; Primorski slovenski biografski leksikon, s.v. "Mandić, Josip"; Leverić, "Josip Mandić", 3-46; particularly detailed about his musical education is Edinost, "Podlistek - Petar Svačić".

2 Lukež was born in Istria in 1869. He completed his schooling in German (in Istria, Trieste, Vienna and Graz), worked as a lawyer, and wrote patriotic verses in Croatian, inspired by the South-Slavic brotherhood. See Znameniti i zaslužni Hrvati, s.v. "Lukež, Karlo”; Car Emin, "Dr. Karlo Lukež"; Strčić, "Preporodni pjesnik Karlo Lukež", 1-38. 
ended and how it would be reestablished by the return of national statehood. The choice of plot suggests that the two artists intended to create a national opera, but, unexpectedly enough, both nation and opera present themselves as needing to be discussed.

Petar Svačić enjoyed a remarkable success at its first concert performance in Trieste in $1903^{3}$ and an enormously enthusiastic audience response at its first theatrical performance in Ljubljana in $1904 .{ }^{4}$ It fell into complete oblivion, however, soon thereafter. Today, just fragments survive: the libretto, published in Pula in 1902, ${ }^{5}$ some contemporary newspaper and journal reviews and a few bits of the score discovered recently by the Croatian musicologist Davor Merkaš. ${ }^{6}$ Certainly insufficient for a musicological analysis, but quite enough - I will dare to say plenty - for an understanding of the cultural, political and social context of a musical event that reflected some important currents of thought in finde-siècle Central Europe. What makes it particularly fruitful for a reflection on "opera and ideas" is that it was conceived and written in an area that is both peripheral vis-à-vis the Austrian empire and remote from the new centres of national cultures then being created: in that periphery, that (non)place, that forces us, by simultaneously lagging behind and anticipating the new, to re-examine and redefine many of the concepts that are often taken for granted in the national and political centres.

History is the main means by which the narrative is constructed that the national

3 The concert was organised by the society Dalmatinski skup, and was held on $19^{\text {th }}$ February at the Rossetti theatre. The society was founded by Croats living in Trieste, but their activities were also supported by Slovenians and Serbs in a common effort to oppose German and Italian cultural domination in the city. Reports on the concert in Croatian and Slovenian newspapers in Trieste welcomed the event as a sign of the growing cultural and economic power of their communities. It is worth noting, however, that Italian and German newspapers also wrote positively about the concert, praising the composer's promising talent. See the non-bylined newspaper articles: Edinost, "Koncert Dalmatinskega skupa", Trieste, "La festa del Club Dalmatino", and Edinost, "O koncertu Dalmatinskega skupa" (the latter is a translation of the article published in Triester Zeitung).

4 The opera could not been staged in Zagreb, since the Hungarian governor of Croatia Károly Khuen-Héderváry abolished opera performances in Zagreb in 1902, and they were staged again only in 1909. The ovations, cheers for the author and demands for encores at the first performance in Ljubljana on $15^{\text {th }}$ January 1904 (there was only one subsequent performance, on $4^{\text {th }}$ February) are described in Edinost, “Triumf mladega hrvatskega skladatelja J. Mandića v Ljubljani”. Unlike the audience, the critics were less positive this time; the theatrical production seems to have brought out the weaknesses of the dramaturgy of the opera. "The vocal part of the opera is not of the same excellence as its orchestral part" states Edinost ("Opera Petar Svačić v Ljubljani”). The journal Ljubljanski zvon considers the plot static and boring, unsuitable for performance and uneasy for the singers, who "don't know what to do with themselves on the stage" (Pahor, "Petar Svačić"). For more details on the performance see Badurina, "Petar Svačić u Trstu", 153-156.

5 Lukež (pseudonym dr. Trnoplesar), Petar Svačić. The libretto had previously been published in the journal Naša sloga.

6 Davor Merkaš gathered scattered pieces of the composer's opus in Prague, Vienna and Opatija. It is also thanks to him that Mandić's later opera, Mirjana (composed in the thirties, with a surrealist content), was staged in Zagreb in 2008.

7 The reference is, of course, to the methodologically pioneering work by Paul Robinson, Opera and Ideas. 
community tells itself about its birth, suffering and survival: a narrative whose powerful mobilising effect derives precisely from the analogy with that of a living being and its need to be protected. For these purposes, however, one particular narrative procedure for the use of historical material is more suitable than others: the template of tragedy. Thus historical events become the story of a guiltless ${ }^{8}$ hero (or community) who is compelled to succumb to catastrophe but gains the moral victory and with it the prospect of future reward. The importance of the elements of tragedy, fatality and moral victory in this narrative pattern has been correlated by Hayden White with the concept of the sublime. ${ }^{9}$ The sublime historical discourse draws mainly on the classical idea of the sublime, and often ignores its romantic developments towards Leopardian melancholy or self-annihilation; it promotes, on the contrary, the sense of offended greatness and the belief in future revenge, often understood as the final realisation of the national state. Sometimes this kind of discourse nurtures a collective sense of being innocent victims in eternal conflict with, and genuinely superior to, the others. This is why this narrative has often been accused of encouraging or even producing nationalisms and providing the full range of $20^{\text {th }}$ century antidemocratic and totalitarian regimes. ${ }^{10}$

A similar narrative pattern was detected by Michel Foucault in English and French historiography of the early $17^{\text {th }}$ century, when history started to be narrated by political historians who renounced the ideals of neutrality, legitimacy and universality, and identified themselves with oppressed communities claiming their rights and desiring a revenge achievable only through war. ${ }^{11}$ The new discourse defended the specificities of the races rooted in language and kinship ${ }^{12}$ and was deeply interested in history as the origin of current unrighteous power relations. Its idea of history is close to mythology, with its motifs of glorious ancestors, sainted heroes, lost golden ages and future restorations typical of cyclical, antimodernist interpretations of the past. Among other examples, Foucault finds this kind of discourse in the $19^{\text {th }}$ century national movements against big empires like the Austrian one. ${ }^{13}$ His analysis, however, is not intended merely to criticise or refute such a discourse. On the contrary, Foucault argues that we should take seriously the connections

8 The absence of guilt is very important for this kind of narrative and requires some specific character types. Since any intentional interference with fate might make the victim seem less innocent, the figure of "the naïve king" began to occur very frequently. According to Darko Suvin, "in this kind of dramaturgy it is almost unpatriotic to be intelligent. On the contrary, the signs of a good Croat are absolute naïvety and political illiteracy" (Suvin, "Norme hrvatske povijesne dramatike", 483). The king in Lukež's libretto is a good example of this type, with his Hamletian doubts before the crowning: "I am too respected [...] I don't know if I merit it." (Lukež, Petar Svačić, 22).

9 White, "The Politics of Historical Interpretation", 113-137.

${ }^{10}$ See, for example, Banti, Sublime madre nostra, 50.

${ }^{11}$ Foucault, Society Must Be Defended, 45-65.

12 The similarity of Foucault's diagnosis with the distinction between "liberal, civic Western" and "illiberal, ethnic Eastern" nationalism made by Hans Kohn in 1944 is only superficial. In describing his type of the "war discourse" Foucault avoids any historical, regional, ideological or evaluative determination, maintaining it as an open and dynamic dispositif, thus permitting its reappearance through the ages in many different forms and areas.

${ }^{13}$ Foucault, Society Must Be Defended, 57-63. 
between war, violence, history and dismissed legitimacy that are displayed by this discourse and are, according to him, particularly visible in the literary genre of historical tragedy. Thus, historical tragedy and, if I may add, national opera, ${ }^{14}$ function as a ritual intersection of these painful issues, including during those historical periods in which a legitimist historiographic discourse prevails.

Nevertheless, the experience of totalitarianism in the $20^{\text {th }}$ century has forced us to view the sublime interpretations of national histories with a certain concern. It was for this reason that one of the most influential Croatian writers of the $20^{\text {th }}$ century, Miroslav Krleža, rejected the whole corpus of $19^{\text {th }}$ century Croatian historical tragedy. In one of his ironic passages, he quoted the popular verse from the Croatian national opera Nikola Šubić Zrinjski ("To arms, to arms, | take your swords out of the scabbards, | brothers!") and added sarcastically that "in the end the brothers actually pulled the swords from their scabbards", alluding to Croatian-Serbian conflicts during the Second World War. ${ }^{15}$ It should be said, however, that much of Croatian $19^{\text {th }}$ historical tragedy, especially those works belonging to high literature and demanding to be performed in national theatres, was speaking, on the contrary, about Croatian-Serbian friendship and South-Slavic brotherhood. Krleža's critique applies more to popular dramas with openly nationalistic propaganda like those written in the same period by Higin Dragošić. In $19^{\text {th }}$ century Croatian culture, unlike in Italy, the opera is much closer to high literature and to the strict genre of historical tragedies in verse than to the popular novel. ${ }^{16}$ Too expensive and too important in national cultural policy, it was not usable for radical nationalist propaganda. The above mentioned Nikola Šubić Zrinjski is the only opera that provoked exclusively Croatian national pathos - and it has continued to provoke it until today - but it speaks about a Croatian battle fought on the side of the emperor of Austria, against the Turks, which renders metaphorical and arbitrary all the interpretations referred to by Krleža (antemurales christianitatis, referring to Catholic defence against orthodox Serbs). One thing is, however, crucial for our analysis: all historical tragedies and operas - high-brow or low, presenting universal human ideals or unadorned nationalism - contain the same sublime pathos of history narrated through the tragic formula.

There is, still, one confusing point regarding the popularity of the sublime historical discourse in the $19^{\text {th }}$ century: the fact that, for other elements in the culture, the second half of the $19^{\text {th }}$ century is the era of desublimation. The development of science and technology, of political ideas aspiring to the improvement of society (liberalism, socialism) and of a certain sense of the general progress of humanity seemed to have created the conditions for the decisive abandonment of mythical discourses. According to George Steiner, this is the time of the "death of tragedy", ${ }^{17}$ in whose place the modern drama was

${ }^{14}$ On the closeness between national opera and historical tragedy, particularly in the Croatian case, see Badurina, Utvara kletve, 271-300.

${ }^{15}$ Krleža, "O našem dramskom repertoaru", 265.

${ }^{16}$ The relation between Italian opera and the popular novel has been described well by Folco Portinari, Pari siamo!, 125-134. Portinari does not mention Antonio Gramsci, but the influence of Gramsci's ideas about Italian melodrama is manifest in his work.

${ }^{17}$ Steiner, The Death of Tragedy. 
born. A Doll's House by Ibsen, for example, was written in the same decade as Nikola Šubić Zrinjski, but belongs to a completely different world. Nora's story suggests that her unhappiness could have been avoided if society had been organised differently: she was not, that is, simply the victim of her tragic fate. The inevitability of classical tragedy (what could Oedipus do, for example, to avoid his fate?) was considered old-fashioned in the new literature. $19^{\text {th }}$-century historical tragedy is, thus, a strenuous attempt to keep sublime pathos alive in a world of desublimation.

These contrasting currents of thought also competed on the very terrain of historiography. Croatian $19^{\text {th }}$ century historiography followed the general trend of scientification, drawing principally on German historicism and believing that it was possible to establish a genuine objectivity that would tell the facts "just as they happened". At the same time, however, the new historiography was not free of political influences, and nor thus of rhetoric forms. One of the aims of Croatian historians' intense, methodical archival research in the second half of the $19^{\text {th }}$ century was to find evidence of Croatia's right to its own state after joining the union with Hungary in 1102, evidence that could be used as a strategic tool in Croatia's diplomatic dialogue with Vienna and Pest. This conjoining of scientific criteria with subjective involvement resulted in histories that combined scientifically proven facts and the story of the tragic and cathartic collective fatum. Tadej Smičiklas, for example, was trained as a historian in Vienna, but his History of Croatia, published around 1880 (and quoted by Lukež as the primary source of his libretto), presented the history of the Croats as a "seamless struggle with stronger and bigger nations who were threatening their survival"; the book was aimed at "motivating the readers to resist foreign rulers and to reach big national goals". ${ }^{18}$

The literary corpus of the period of Croatian national awakening contains many works about Petar Svačić and his predecessor, king Zvonimir, also regarded as the last king (Svačić was, legally, only a pretender). They were both victims of betrayal by their own people (hence the topos of "Croatian discord", also present in Lukež's text). According to the legend, Zvonimir pronounced a deathbed curse that his own people would not have their own state for centuries, and this became the very heart of Croatia's tragic fatalism. ${ }^{19}$ In 1902, when Mandić and Lukež chose the topic for their opera, the Zagreb literary critic Branko Vodnik offered a severe diagnosis of what he called "the abnormal moment in the development of our literature". ${ }^{20}$ Some years later he would explain: "In our historical dramas the characters are nothing else than sentimental patriots, demagogues and journalists of political fractions, dressed in the clothes of Tomislav, Svačić and Petar Zrinski [...] these characters satisfy the nerves of a sick political chauvinism". ${ }^{21}$ Focused on Croatian history and wearing old historicist clothes, these works very rarely mention Serbs who, in fact, were not involved in those historical events. The only exception is

${ }^{18}$ Gross, Suvremena historiografija, 178.

19 The re-establishment of Croatian national independence in 1991 was often interpreted by leading politicians and media of the time as the end of the Zvonimir's curse, which attests the vitality of the sublime historical discourse.

${ }^{20}$ Vodnik, "Abnormalni momenat", 20.

${ }^{21}$ Vodnik, Franjo Marković. Studija, 94-95. 
probably the tragedy by Jovan Subotić, a Serbian author working in Zagreb, who used the story of Zvonimir, very loosely, in order to create an amusing drama about CroatianSerbian friendship in 1862 . His tragedy was very successful, being staged at the national theatre in Zagreb to mark Zvonimir's anniversary in 1876, but it was still just a populist elaboration of Illirian heritage, and quite obsolete in the new political arena of the time.

During the second half of the $19^{\text {th }}$ century the idea of South-Slavic brotherhood, although promoted by Croatia's main political party, underwent a crisis and opposition to it gained ground through the influence of the radical Party of Rights (the "rights" here referred primarily to Croatia's right to independent statehood) before finally, towards the end of the century, growing again as a concrete political programme. The literature that accompanied this new Yugoslav ideology, early literary modernism, promoted new poetics, quite different from the historicism that had dominated the historical tragedies of the Croatian past written in the second half of the $19^{\text {th }}$ century. Because of the lack of a common Croatian and Serbian political or institutional medieval history, the new poetics used abstract, atemporal and symbolic elements drawn from folk epics and songs about Croatian and Serbian heroic battles against the Turks. The new poetic depicting Slavic brotherhood was, thus, less historical and more "provocatively irrational". ${ }^{22}$

The anomaly of Mandić and Lukež's operatic project remains in the fact that they chose the Croatian historicist theme of Petar Svačić, but they arranged it with the poetic tools that were used in the art of their time to promote the idea of the union of Southern Slavs. Although the theme did not permit this idea to be explicitly mentioned, there are many undoubtable references to it. The Prologue of the opera, placed after the overture, is written in decasyllabic verses and simulates the folk epic with its whole repertoire of rhetorical figures, including the "Slavic anthitesis" (question -two hypotheses - negation of the hypothesis - correct answer). It was sung by a baritone dressed as a gusle player, and, according to newspaper critics, the music was heavy and monotonous, recalling the genre of the folk song. The verses of the Prologue Rode rode, zar ti do slobode | $i$ do čast $i$ stalo toli malo? ("Do you, my people, care so little about freedom and honour?"), in which the term rod (people) is intended to convey Croatian and Serbian kinship, are repeated at the very end of the opera, thus making clear what is its essential political meaning. The language elsewhere in the libretto also contains lexical and stylistic elements of the common Croatian and Serbian folk heritage, like fixed epithets (mrki Vuče) and animal metaphors (the king a hawk, the queen a turtledove). The folk epic worldview introduces a cyclical vision of history, in which the collective trauma is relieved by the belief that all the suffering will be remembered in folk song. ${ }^{23} \mathrm{All}$ this must have led the spectator to associate the crucial battle scene in which Svačić dies with another topos: that of the battle of Kosovo polje, the epic Serbian defeat by the Turks in 1389 and the basis of the Serbian myth of lost statehood, which has been extensively elaborated in folk songs.

The specificity of this assemblage can be understood only within the peripheral and transnational context of Trieste at the turn of the century. The two young authors were

${ }^{22}$ Kravar, "Ideologem nacionalnog srednjovjekovlja", 165.

${ }^{23}$ Observing the battle from the hill, the queen comforts herself: "Into the distant future the guslar will still sing | About this Croatian glory”. Lukež, Petar Svačić, 32. 
colleagues on the Croatian journal edited in Trieste, Jadran; Mandić wrote articles about music, ${ }^{24}$ while Lukež worked as the editor and stood in for the editor-in-chief, Ante Tresić Pavičić, when he was away. The journal was launched with the intention of promoting radical Croatian politics, ${ }^{25}$ and Tresić Pavičić, who was among the most respected Croatian authors of historical tragedies, was at the time close to the Party of Rights. However, the multi-national competition for cultural and economic domination in Trieste and the Slavic communities' need to oppose the much stronger German and Italian influences induced Jadran and his editors to become more open towards the heritage of the Illirian idea, which had never faded in this area. ${ }^{26}$ For the same reason the two young authors re-elaborated the Croatian pathos that was implicit in the theme of Petar Svačić and redirected it towards the new Yugoslav ideology, combining the use of elements of the folk tradition in the traditional Illirian literary manner with the new modernism, in a highly stylized form in terms both of plot and of music.

The modernism is also, however, manifest in another aspect of the opera, in a detail of the plot that tarnishes its otherwise perfect aura of sublimity. In any sublime narrative, the death of a hero is essential; it is the martyrdom out of which grows the promise of the future resurrection of the whole community. The survival of a knight in battle can bring that indelible shame on which whole tragedies might be built (Siget by Higin Dragošić, for example). In Lukež's libretto, conversely, the king's main companion, his bravest soldier with the glorious name Vuk (the wolf), flees the battlefield and fetches up alive before the astonished queen. He justifies his decision thus: "I don't crave | to go to the grave |

${ }^{24}$ Mandić had short news items about musical events in the first numbers of 1903, and the article "Nekoliko refleksija". The article criticises the fashion in Italian romantic opera of reducing Wagner's style to musical and theatrical exaggeration. Puccini's Tosca, according to Mandić (who attended its performance in Trieste, in March 1903), seduces its spectators with its dramatic tension, abundance of blood, sufferings, torture, violence and death. Mandić advocates a return to moderation and good taste in both music and plot, without, however, blaming the audience for their enthusiasm.

${ }^{25}$ The opening article by Tresić Pavičić, "Program Jadrana", is sufficient evidence of this intention. It was noticed immediately by the Slovenian journal Edinost (in the short news item "Na polju slovanskega novinarstva", 3 March 1903).

${ }^{26}$ The first period during which the Illirian idea was promoted in Trieste, starting in 1836 with the journal La Favilla, is described accurately by Cavallini in "Morlacchismo, illirismo, involuzioni esotiche", 375-382. Cavallini notes the curious absence of Slovenians from the journal's Illirian project, ascribing it to a fear on the part of its writers that the Slovenian language - which is quite unlike Croatian and Serbian - might undermine the imaginary South-Slavic homogeneity. The supposition of this fear was also supported by the fact that none of the main Slovenian intellectuals and writers from the central national territory (apart from Stanko Vraz) joined the Illirian movement. In this connection it is interesting to observe the relations between the Triestine Slavic communities some decades later, at the time of the opera Petar Svačić. The desire to hold together is still visible, as we saw above in the reactions to the concert production of Mandićs opera. Tresić's journal, however, contains many articles describing the serious difficulties the three communities met in trying to collaborate, with frequent mentions of the language barrier between the Slovenes and the Croats and the Serbs as the main reason for this (see, for example, Jadran, 1904, n. 23). For historic data about Slovenian-Croatian economic and cultural relations in Trieste see Pahor, Slavjanska sloga. 
now, when my death | would be of no help | to my sad country. | [...] If the sword | can't serve any longer, | what's the use of the tears?". The statement is left without comment by the queen or the others, but since Vuk declares that he would hide Svačić's crown to prevent the foreign ruler seizing it, it is clear that the action of leaving the battelfield has not disqualified him from becoming the custodian of the continuity of the Croatian state. The idea that there is no purpose in dying, that it is better to survive and to be useful to your country in some other way than martyrdom, belongs to the rationalism and optimism of the bourgeois world which, according to Steiner, killed tragedy. Practical reasoning characterised the politics of those years, particularly among the young Croatians who emigrated to Prague after 1895 and became ardent followers of Tomáš G. Masaryk. ${ }^{27}$ The article "What we want", published in the launch issue of their journal Hrvatska misao in Prague in 1897, used the quotation mentioned above from Nikola Šubić Zrinjski as the clearest, best known and most self-explanatory symbol of the old fashioned romantic nationalism: "Croatian young people today are full of romanticism, they still sing 'To arms! to arms!' and with the highest enthusiasm they pronounce 'Let the Turk know how we die'. We want these young people to start thinking realistically, to understand that the Croatian people are at the limit of their endurance, they are desperate, in moral decadence and material extinction. Thus, instead of enthusiastic toasts, telegrams and declarations of loyalty, we ask for rigorous work in the economic, educational and political fields". ${ }^{28}$ Another summary of the new programme was written in the same journal by Milan Šarić: "Everyone wants to die for their country, is there anybody who would like to live and work for the country?" 29 Lukež and Mandić were evidently part of this same generation. The problem, however, remains the fact that they introduced their modernist ideas in the sublime world of the national historical opera. Is this not risking the death of opera, just as happened to tragedy?

The classical work on the death of the opera, written in 1980 by Philippe-Joseph Salazar adopts a sociological, semiotic and anthropological approach. ${ }^{30}$ The reason for the death of the opera, which for Salazar happened at the beginning of the $20^{\text {th }}$ century, consists in the excessive rigidity of the operatic roles, which is strictly related to the singers' voices and to the male-female binarism (the king is baritone, the queen soprano etc.) of the bourgeois and patriarchal family model. ${ }^{31}$ Such rigid schemata could not survive

${ }^{27}$ Masaryk's influence on Croatian, Slovenian and Serbian students has been widely researched in history and literature. Gantar Godina's Masaryk in masarykovstvo, 22-44, is worth quoting here for its focus on the different views of individual national communities on the idea of South-Slavic unity. Czech influences in Croatian literary journals are analysed in Šabić, Iz zlatnog Praga, 149-170. For an historic overview of the Czech presence in Trieste see Klabjan, Češkoslovaška na Jadranu.

${ }^{28}$ Quoted in Gantar Godina, Masaryk in masarykovstvo, 22-23. The author of the article is, very probably, Stjepan Radić.

${ }^{29}$ Quoted in Frangeš, Povijest hrvatske književnosti, 232.

${ }^{30}$ Salazar, Ideologije u operi. Salazar's inspiring ideas have recently been applied in Vlado Kotnik's anthropological analysis, Antropologija opere and Kotnik, Opera, Power and Ideology.

${ }^{31}$ This distribution of roles was followed only a year later in Italy by Folco Portinari (Portinari, Pari siamo!, 4). See also Chiappini, O patria mia, 5-18, 96, 103, about the opera's job of masculinizing 
long in the modernist era of innovation and transformation in social roles. The mortality of the opera, according to Salazar, derives from its being inseparably bound to its society. This bond is intended to refer not simply to how opera reflects society but also to the way in which any artistic work is part of the discourse, and thus promotes political practices that produce meanings. The analysis of the relationships that the opera establishes with other parts of the discourse - relationships that together form the society - is exactly the type of archeological research that Salazar advocates for the restoration of the essential historicity of the opera.

Although fully engaged in showing the utility of the sociological approach to the opera, towards the end of his essay Salazar discusses the ideas of Feruccio Busoni, who tried in the 1920 s to give new life to the opera by liberating it from its referentiality and its social context. For Busoni the opera should find its roots in the voice, not the words, thus liberating it from everything that ties it to drama or theatre. What intrigues Salazar in Busoni's theory is the fact that, once liberated from language and meaning, the voice evades sociological analysis. The opera does not belong entirely to the language - or, as Salazar puts it in concluding his comments - "the opera is an uncomfortable question for the humanities". ${ }^{2}$

Salazar's discussion of Busoni is important for the methodological question of whether the reading of the libretto is a valid basis for the study of the opera. It also relates quite interestingly with some recent theories on the voice. Giorgio Agamben's philosophical approach to voice and language, ${ }^{33}$ the Lacanian interpretation in Mladen Dolar ${ }^{34}$ and the feminist questioning of the same problem in Adriana Cavarero ${ }^{35}$ share the idea that there is a voice that escapes language and reason, that exists before the word, and alludes to the unspeakable. While it is true that what alludes to the unspeakable Idea or Thing is, from Kant to Leopardi, the sublime, it is also clear that this is not the kind of political sublime described in Hayden White. On the contrary, this sublimity belongs to the voice that is dissociated from society. The sublimity of the voice is an always relevant warning against any easy sociological analysis of the opera. There are always some "remnants", some sublime and/or traumatic experiences, that cannot be narrated or analysed.

On the other hand although the voice precedes linguistic expression, it is also true that it cannot be separated from the uttered word. The voice makes the word possible, and is inscribed in it, contained within language, meaning and sociability. A simple exteriority from language does not exist. The inseparable "politics of the voice" echoes for Dolar the impossibility, explained by Agamben in Homo sacer, of the bare life (vita

the nation. Despite the urge to greatness detectable in the Mandić's two-hour orchestration, the plot of Petar Svačić had had to be tailored to fit the numbers of singers available: unlike the classical pattern of historical operas with two couples at the centre of the plot (the mature king and queen, and the young lovers), in Petar Svačić there is only one male-female couple: their relationship is that of young lovers in the first part and of mature and responsible rulers later on. The king is, thus, sung by a tenor.

${ }^{32}$ Salazar, Ideologije u operi, 213.

${ }_{33}$ Agamben, Quel che resta di Auschwitz, 36.

${ }^{34}$ Dolar, A Voice and Nothing More, 34-57.

${ }^{35}$ Cavarero, A più voci, 43-52. 
$n u d a$ ) outside the polis. ${ }^{36}$ It seems that Salazar encountered exactly this aporia when, at the end of his book, he admitted that the theoretical attempt by Busoni to give new life to the opera by freeing it from words and social roles has failed. Despite Busoni's experiment, the opera remained inseparably linked to historical contingency. But despite his pessimism, it also survived.

Salazar's final surrender before the historicity of the opera permits us to reflect on the opera even when all that remains is libretto, a few pages of the score and some newspaper reviews. It seems, too, that reflecting on Mandić and Lukež's work can still be meaningful today in at least two senses, mirroring its inherent and inspiring inconsistencies. In the first place, it is a reminder of the importance of understanding those who, feeling humiliated, need to tell their own history on the sublime scale. At the same time, and no less importantly, it reminds us of the need to retain our rational control over all the ways of presenting history as tragic fatality. Therefore, while enjoying the national operas, we should be as shrewd as Ulysses: listen to the mermaid's voices, but resist their sublime appeal. ${ }^{37}$

\section{Bibliography}

Agamben, Giorgio. Quel che resta di Auschwitz. Torino: Bollati Boringhieri, 1998. Badurina, Natka. "Petar Svačić u Trstu 1903”. In N. Badurina, Nezakonite kćeri Ilirije,143-159. Zagreb: Centar za ženske studije, 2009.

Utvara kletve. O sublimnom i rodnim ulogama u hrvatskoj povijesnoj tragediji u 19. stoljeću. Zagreb: Disput, 2014.

Banti, Alberto Mario. Sublime madre nostra. La nazione italiana dal Risorgimento al fascismo. Rome: Laterza, 2011.

Car Emin, Viktor. "Dr. Karlo Lukež - tragična smrt istarskog pjesnika". Novosti, 12 December 1930.

Cavallini, Ivano. "Morlacchismo, illirismo, involuzioni esotiche. L'immagine degli slavi del sud nel teatro e nella musica dell'Ottocento in Italia / Morlakizem, ilirizem, eksotična zamotanost. Lik južnega Slovana v italijanskem gledališču in glasbi devetnaestega stoletja”. In: Trst: umetnostni izraz ob nacionalnem vprašanju. Glasba, likovna in besedna umetnost ob slovensko-italijanski meji v drugi polovici XIX. stoletja do prihoda fašizma, edited by Aleksander Rojc, 363-429. Trieste: Glasbena matica; Ljubljana: Založba ZRC, ZRC SAZU, 2014.

Cavarero, Adriana. A più voci. Filosofia dell'espressione vocale. Milano: Feltrinelli, 2005. Chiappini, Simonetta. O patria mia. Passione e identità nazionale nel melodramma italiano dell'Ottocento. Firenze: Le lettere, 2011.

Dolar, Mladen. A Voice and Nothing More. Cambridge and London: MIT Press, 2006.

Edinost, "Koncert Dalmatinskega skupa", 20 February 1903.

Edinost, "O koncertu Dalmatinskega skupa", 21 February 1903.

${ }^{36}$ Dolar, A Voice and Nothing More, 104-106.

${ }^{37}$ I borrow this metaphor from Kravar, Uljanice i duhovi, 68. 
Edinost, “Opera Petar Svačić v Ljubljani”, 17 January 1904.

Edinost, "Podlistek - Petar Svačić", 15 January 1904.

Edinost, “Triumf mladega hrvatskega skladatelja J. Mandića v Ljubljani”, 16 January 1904.

Foucault, Michel. Society Must Be Defended. New York: Picador, 2003.

Frangeš, Ivo. Povijest hrvatske književnosti. Zagreb and Ljubljana: NZMH and Cankarjeva založba, 1987.

Gantar Godina, Irena. T. G. Masaryk in masarykovstvo na Slovenskem (1895-1914). Ljubljana: Slovenska matica, 1987.

Gross, Mirjana. Suvremena historiografija. Zagreb: Novi Liber and Zavod za hrvatsku povijest Filozofskog fakulteta, 2001.

Klabjan, Borut. Češkoslovaška na Jadranu. Čehi in Slovaki ter njihove povezave s Trstom in Primorsko od začetka 20. stoletja do druge svetovne vojne. Koper: Univerza na Primorskem, Znanstveno-raziskovalno središče, Založba Annales, 2007.

Kotnik, Vlado. Antropologija opere. Pomen idej o operi za razumevanje opernega fenomena in imaginarija. Koper: Univerza na Primorskem, Znanstveno-raziskovalno središče, Zgodovinsko društvo za južno Primorsko, 2005.

Opera, Power and Ideology. Anthropological Study of a National Art in Slovenia. Frankfurt am Main: Peter Lang, 2010.

Kravar, Zoran. "Ideologem nacionalnog srednjovjekovlja u Nazorovim Hrvatskim kraljevima”. In: Književni protusvjetovi, edited by N. Batušić, Z. Kravar, V. Žmegač, 163-167. Zagreb: Matica hrvatska, 2001.

Kravar, Zoran. Uljanice i duhovi. Zagreb: Profil, 2009.

Krleža, Miroslav. "O našem dramskom repertoaru” (1948). In M. Krleža, Eseji I, 249-269, Sarajevo: Oslobođenje, 1973.

Leverić, Nataša. “Josip Mandić (1883.-1959) - tragovi”. Arti musices 30, no. 1 (1999): 3-46.

Lukež, Karlo [dr. Trnoplesar]. Petar Svačić. Prigodom 800-godišnjice njegove smrti. Opera u dva čina sa prologom. Dramatska radnja dra. Trnoplesara. Uglasbio Josip Mandić. Pula: Naklada tiskare J. Krmpotić i dr., 1902.

Mandić, Josip. "Nekoliko refleksija”. Jadran, 25 April and 9 May 1903.

Muzička Enciklopedija. Edited by Josip Andreis. Vol. 2. Zagreb: Jugoslavenski leksikografski zavod, 1963.

Pahor, Leopold. "Petar Svačić". Ljubljanski zvon 24, no. 2, 1904: 122-123.

Pahor, Milan. Slavjanska sloga. Slovenci in Hrvati v Trstu od avstroogrske monarhije do italijanske republike. Trst: ZTT - EST, 2004.

Portinari, Folco. Pari siamo! Io la lingua, egli ha il pugnale. Storia del melodramma ottocentesco attraverso i suoi libretti. Torino: EDT, 1981.

Primorski slovenski biografski leksikon. Vol 2. Gorica: Mohorjeva družba, 1974-1994.

Robinson, Paul. Opera and Ideas. From Mozart to Strauss. Ithaca and New York: Cornell University Press, 1986.

Salazar, Philippe-Joseph. Ideologije u operi. Translated by Ivanka Pavlović. Beograd: Nolit, 1985. (Translation in Serbian of Idéologies de l'opéra, Paris: Presses universitaires de France, 1980.)

Steiner, George. The Death of Tragedy. 2nd edition. Oxford: Oxford University Press, 1980. 
Strčić, Mirjana. "Preporodni pjesnik Karlo Lukež". In Lovran u XIX. stoljeću, 1-38, Lovran: Poglavarstvo Općine Lovran, 1998.

Suvin, Darko. "Norme hrvatske povijesne dramatike do 'Dubrovačke trilogije'." Forum 3 (1971): 457-492.

Šabić, Marijan. Iz zlatnoga Praga. Češka književnost i kultura u hrvatskoj književnoj periodici 1835-1903. Zagreb: Filozofski fakultet i Hrvatski institut za povijest, 2008.

Tresić Pavičić, Ante. "Program Jadrana". Jadran, 11 April 1903.

Trieste, "La festa del Club Dalmatino", 20 February 1903.

Vodnik, Branko. "Abnormalni momenat u razvitku hrvatske knjige". Mlada Hrvatska, 1 (1902): 20-27.

Vodnik, Branko. Franjo Marković. Studija. Zagreb: Naklada knjižare Gj. Trpinca, 1906.

White, Hayden. "The Politics of Historical Interpretation: Discipline and De-Sublimation". Critical Inquiry 9, no.1 (1982): 113-137.

Znameniti i zaslužni Hrvati. Zagreb: Hrvatski štamparski zavod, 1925. 


\section{HRVAŠKI ZGODOVINSKI MIT, JUŽNOSLOVANSKO BRATSTVO IN SMRT OPERE}

\section{Povzetek}

Libreto Karla Lukeža, nekaj strani partiture in številne časopisne kritike so ohranjene sledi opere Petar Svačić, ki jo je Josip Mandić zložil leta 1902 v Trstu. Čeprav ohranjeno gradivo ne zadostuje za muzikološko analizo, nudi možnost za razmislek o tedanjih narodnostnih idejah mladih Hrvatov, o preživetju patosa sublimnosti v obdobju desublimacije in o vplivu političnega pragmatizma na ustvarjanje in recepcijo nacionalne opere.

Mandićeva opera obravnava hrvaški zgodovinski mit o smrti zadnjega kralja in izgubi narodove državnosti. Dogodek je predstavljen skozi diskurz o sublimnem, ki je bil ključen tako za proces izgrajevanja nacionalne zavesti kot tudi za samo opero. Značilnosti zgodovinskega diskurza o sublimnem so predstavljene s sklicevanjem na Haydna Whita in Michela Foucaulta, s posebnim ozirom na možne povezave z nacionalizmom in militarizmom ter odgovornosti zanju.

Tematika v operi Petar Svačić ni predstavljena z značilnim historicističnim pristopom, tipičnim za 19. stoletje, pač pa s poetskimi, jezikovnimi, slogovnimi in glasbenimi elementi južnoslovanskih ljudskih pesmi in z jasnim namenom podpiranja jugoslovanske ideje. Razprava pojasnjuje takšno poetiko $\mathrm{v}$ povezavi s posebnostmi tedanjih političnih razmer $\mathrm{v}$ Trstu in s potrebo slovanske skupnosti po skupnem uporu proti italijanski in nemški kulturni prevladi v tem mestu. Druga posebnost, ki spodbuja razmislek, je odmaknitev od patosa sublimnosti v zadnjem prizoru drugega dejanja, ko se vitez upira smrti v bitki. Ta ideja je obravnavana v smislu vpliva novih pragmatičnih političnih idej modernizma na tedanje hrvaške študente, še posebno misli Tomáša G. Masaryka.

Prisotnost anti-junaškega elementa močno nakazuje odklon nacionalne in/ali zgodovinske opere od čisto mitološkega, tragičnega in fatalističnega nazora. Obravnavana je razprava Philippa-Josepha Salazarja o smrti opere in njegove opombe k Busonijevi ideji o operi, ki je zakoreninjena v čisto vokalnem in osvobojena zgodovinskosti.

V zaključku razprava sprejema Salazarjevo tezo o neizogibni zgodovinskosti opere in uporabnosti sociološkega pristopa k njenemu preučevanju. Kot lahko vidimo iz tega obrobnega, toda pomembnega glasbenega dogodka, je zgodovinskost opere še danes relevantna in zgovorna. 
